\title{
Editorial
}

\section{GLOBALIZATION: where you stand depends upon where you sit}

Over the last decade, the phenomenon of globalization has captured the imagination of academics, policy-makers and the wider public throughout the Western world. Since the collapse of Marxist/Leninism and the Soviet Empire in 1989 the triumph of US-style liberal democracy and its most important offshoot, globalization, has become the defining leitmotif of postmodern society. This is what the Americans meant by 'the end of history' that free market liberalism had in the twentieth century decisively beaten out of sight all rival political, social and economic arrangements, particularly fascism and communism. In the new millennium therefore, globalization is the only game in town.

The force that drives globalization is free market capitalism - the more you let market forces rule, the more you succeed in your quest for prosperity and wealth. The world is a 'global village'. And like all villages, the market place is the centre of activity. In every market there are winners, losers, buyers, sellers, and inevitably, beggars who are the downside of all economic systems of production and distribution. Nevertheless, the idea is that in the end everyone wins - through their own endeavours or failing that, through the 'trickle down effect'.

Globalization represents the new international system which has replaced the Cold War order. More than anything else, it is shaping the world we live in. It affects all of us, at every level of our lives whether we are aware of it or not. The unprecedented integration of markets, states and technology is driving change across the globe at astounding speeds, creating at the same time vast wealth for some and devastating poverty for others. For many outside the Western world, the 'win-win' situation in the liberal model is far from a reality. Ten years of accelerated globalization has certainly not eradicated poverty from the face of the earth. On the contrary, the World Bank has estimated that the number of people living on less than $\$ 1$ a day rose from 1.2 billion in 1987 to 1.5 billion in 1997. This is why some critics of the process refer to it as a form on 'global apartheid' (Alexander 1966).

In many parts of the world 'globalization' has become a synonym 'Americanisation' and all that it entails - consumerism, Coco Cola, Big Macs, CNN, Hollywood, the breakdown of the family and so on. Indeed, one could reasonably argue that the International crisis we are currently living through - the war against terrorism - is the 'first war of the globalization effect'. On one side are the 'globalists' represented by the rich, liberal, postindustrial Western sates who have embraced the future and are determined to make it work. On the other are the 'rejectionists represented in this instance by the Taleban and Osama bin Laden's Al Quaeda group who are portrayed as mediaeval, pre-modern religious zealots, fanatically antiWestern and determined to maintain the purity of traditional values, mores and cultures. For people in the cozy West, there are the anti-diluvians who are prepared to die rather than face up to the inevitable consequences of modernization, development and globalization.

For these out-of-the-loop people, globalization represents, albeit in a very subtle way, the latest manifestation of what in an earlier age we bluntly called imperialism or colonialism. This time though, the agents of conquest are money, resources, stock markets, technologies, investments and ideologies. It amounts to a "clash of civilizations' between the west and the rest.

Primary health practitioners throughout the world have long been on the front line dealing with the impacts of gloabilization on individuals: restrictions on state welfare benefit systems, the increase in TB and other communicable diseases, the plight of refugees and economic migrants travelling vast distances to escape wars or to gain material benefits, the problems of access to drugs 
and patent restrictions (Leader, 2001). But what is globalization? What benefits and harms does it generate? How are we to react to it?

\section{Definitions of Globalization:}

As with all core concepts in the human and social sciences the precise meaning of globalization is contested. However, the common elements in most accounts are that it is about 'a borderless world' especially in terms of trade, commerce and finance; it is about internationalization, interdependence, universalization; it's about the Internet, the communications revolution, the wired world, and the collapse of the time-space distinction (Held and McGrew, 2000). It is about all these things and more, in other words, it has material, spatio-temporal, and ideological elements all rolled into one all-embracing notion.

Whether we understand it, like it or loathe it, it now conditions virtually every aspect of our lives. Through micro-chips, satellites, fibre-optics and the web we can travel and barter wherever we please. Today we can ply our trades, from medical advice to plumbing to finance speculation, to astrology, on a global basis without much trouble or coat or indeed without even leaving home. For the first time in history we can interfere in anyone's life, in any place at any time at the touch of a button. It is no wonder that it generates such fierce controversy. We cannot escape from it.

The interaction between globalization and the old forces of culture, history, geography, tradition and community is something we all have to think about. Sooner rather than later we must ask, are we for it, or against it? Does it help us or hinder us? Where do we stand as health care professionals? Our jobs, community, workplace, practice population can be changed at any moment by the impact of globalization. Is it a good thing or a bad thing?

\section{Supporters and detractors}

Its supporters are generally to be found amongst the management gurus, consultants and financial wizards of Wall Street, the City of London, Silicon Valley and the World Bank: the champions of new technologies, corporate bosses, Europhiles and Third Way politicians anxious to be seen to be swimming with the tide of history. Supporters are generally those who welcome new ideas, new skills and multitasking. They are not afraid of inno- vation and change. They are aware of the benefits of the 'creative destruction' that inevitably accompanies globalization: that is, throwing out the old inefficient methods and replacing them with newer more efficient ones. Sure, they acknowledge, it comes at a cost. But in the end we all benefit. After all you cannot stop progress.

Its detractors come in two varieties: in the West they are mainly radical grass roots activists who oppose the rule of global corporations and whose badges of honour include the battles of Seattle and Genoa, eco-warriors and environmentalists; dissident academics and left leaning politicians who cling to 'critical' or Marxian analyses of the bases of social and economic organization and who argue that globalization is immoral as it just makes the rich richer and the poor poorer.

In the global South (or the 'Third World' as it used to be called) the main opponents are religious revivalists and reactionary nationalists who grieve at the damage inflicted on their traditional cultures and beliefs by the deluge of images, ideas, music and artefacts that capture their young and erode their sense of group identify. They are joined in opposition by Third World intellectual elites who witness (usually from a safe distance) the suffering imposed by the effects of global governance agencies like the International Monetary Fund (IMF), the World Bank, and the World Trade Organization (WTO).

These scholar-activists argue that together the three ugly sisters of globalization (IMF, World Bank, WTO) have usurped power from states, and local governments on the alter of their own profit-motivated agendas. Thus, in developing states, health and welfare policies, for example are secondary policy concerns and must give way to the primary business of managing the economy and generating wealth. In the interests of 'global competitiveness' governments are told that they must cut back on social provisions. Only when market forces are in place will the benefits of a sound economic base 'trickle down' to the masses. The instruments used are the 'conditionality clauses' and Structural Adjustment Programmes (SAS) that global bureaucrats insist upon before loans or grants-in-aid are forthcoming. For globalists this is the only magic bullet that is effective; but like all bullets it will hurt before it takes effect. 


\section{Conclusion}

Wherever you stand in the debate, it is obvious that there are many harms and many gains involved in the uneven march of globalization: harms that impact on primary health care as on all aspects of peoples' lives. The trick is to recognise this; to see it as a potentially emancipatory force that needs careful husbandry. Allowed to run rampant it can undermine all sense of community, camaraderie, individuality and civilised values. Tamed, it can increase efficiency, welfare and be a force for positive social change. The trouble is, where and how do we begin? How do we strike the right balance between efficiency, the pursuit of prosperity and social justice for all?
Graham Evans, Senior Lecturer in International Relations University of Wales Swansea Wales, UK Email: G.Evans@swansea.ac.uk

\section{References}

Alexander T 1996 Unravelling Global Apartheid. Polity Press, Cambridge

Held D \& McGrew A 2000 The Global Transformations reader. Polity Press, Cambridge.

Leader 2001 Patent problems pending. The Economist 361(8245): 14

\title{
Primary Health Care Research and Development - Online access
}

\begin{abstract}
s online
The abstracts and key words of each issue of Primary Health Care Research and Development are available to view online free of charge - often in advance of the paper publication. Please sign in as a guest on the ingenta website if you are not already an institutional subscriber:

$$
\text { www.ingenta.com }
$$

\section{Full text download}

Institutional subscribers are also able to download the full text of each article. Once payment has been made to Turpin Distribution Services (see subscription details), the online registration form should be completed at:

$$
\text { www.ingenta.com/home/fs_registernow.htm }
$$

Please have your customer number available. A username and password will then be allocated to allow you to gain access to the full text of articles via the ingenta website. Alternatively contact:
\end{abstract}

\section{Email: help@ingenta.com}

\section{Home page}

The journal home page is available at:

www.phcrd.com

The Terms and Conditions of use together with a list of intermediaries through which the journal is also available can be found on the Arnold website:

www.arnoldpublishers.com/journals 